OPEN ACCESS

Edited by:

Dirk Balmer,

Syngenta Crop Protection,

Switzerland

Reviewed by:

Karabi Datta,

University of Calcutta, India

Peng Zhang,

Chinese Academy of Sciences, China

*Correspondence:

Yongjun Lin

yongjunlin@mail.hzau.edu.cn

Specialty section:

This article was submitted to

Plant Biotic Interactions,

a section of the journal

Frontiers in Plant Science

Received: 18 June 2016

Accepted: 12 October 2016

Published: 27 October 2016

Citation:

Ling $F$, Zhou $F$, Chen $H$ and Lin $Y$

(2016) Development of Marker-Free

Insect-Resistant Indica Rice by

Agrobacterium tumefaciens-Mediated

Co-transformation.

Front. Plant Sci. 7:1608.

doi: $10.3389 /$ fpls.2016.01608

\section{Development of Marker-Free} Insect-Resistant Indica Rice by Agrobacterium tumefaciens-Mediated Co-transformation

\author{
Fei Ling, Fei Zhou, Hao Chen and Yongjun Lin*
}

National Key Laboratory of Crop Genetic Improvement, National Center of Plant Gene Research, Huazhong Agricultural University, Wuhan, China

Agrobacterium-mediated co-transformation is an efficient strategy to generate markerfree transgenic plants. In this study, the vectors pMF-2A* containing a synthetic cry $2 A^{*}$ gene driven by maize ubiquitin promoter and pCAMBIA1301 harboring hygromycin phosphotransferase gene (hpt) were introduced into Minghui86 (Oryza sativa L. ssp. indica), an elite indica restorer line. Two independent transformants containing both the cry2A* gene and hpt gene were regenerated. Several homozygous markerfree transgenic progenies were derived from family $2 \mathrm{AH} 2$, and three of them were selected for further insect bioassay in the laboratory and field. Insect-resistance assays revealed that all the three transgenic lines were highly resistant to striped stem borer (Chilo suppressalis), yellow stem borer (Tryporyza incertulas) and rice leaf folder (Cnaphalocrocis medinalis). The measurement of Cry2A protein concentration showed that Cry2A protein was stably expressed in leaves and stems of homozygous transgenic lines and their hybrids. The yields of the marker-free homozygous transgenic lines and their hybrids were not significantly different from those of their corresponding controls. Furthermore, the results of flanking sequence isolation showed that the T-DNA in line 8-30 was integrated into the intergenic region of chromosome 2 (between Os02g43680 and Os02g43690). These results indicate that the marker-free transgenic rice has the potential for commercial production.

Keywords: co-transformation, cry2A, insect-resistant, marker-free, transgenic rice

\section{INTRODUCTION}

Rice is one of the most important staple food crops in the world. Insect damage can cause severe rice yield loss up to $10 \%$ every year (Chen et al., 2009). Rice leaf folder, striped stem borer (SSB), and yellow stem borer (YSB) are three major pests in rice production. Traditionally, chemical pesticides are used to control these pests, which cause a series of problems, such as environmental pollution, pesticide residue and increase of production cost. Bt proteins have been widely used as a bioinsecticide and the $B t$ genes have been 
introduced into rice, corn, cotton, soybean, and other crops to control pests, such as Lepidoptera pests. Transgenic crops such as corn and cotton that express Bt proteins for commercial application have brought great economic benefits (Clive, 2012).

Currently, Agrobacterium tumefaciens-mediated genetic transformation is widely applied to the development of transgenic crops, and antibiotic or herbicide-resistant selectable marker genes (SMGs) are used to select transformed cells in the transformation process. SMGs are redundant after transformation, and are not conducive to continuous transformation and safety. Thus, a series of marker-free strategies were developed, such as biolistic method ( $\mathrm{Tu}$ et al., 2000; Shiva Prakash et al., 2009) and A. tumefaciens-mediated co-transformation, site-specific recombination (Li et al., 2007; Qiu et al., 2010; Sengupta et al., 2010; Yu et al., 2013; Woo et al., 2015b), multi-auto-transformation vector system (Endo et al., 2002; Khan et al., 2006; Scaramelli et al., 2009), transposonmediated method (Gao et al., 2015), intrachromosomal recombination (Zubko et al., 2000), and PCR-based method (de Vetten et al., 2003; Woo et al., 2015a). There are three approaches for the co-transformation: one plasmid harboring two T-DNAs in one Agrobacterium strain (Breitler et al., 2004; Matheka et al., 2013); two T-DNAs located on two plasmids in the same Agrobacterium strain (Parkhi et al., 2005; Sripriya et al., 2008); two T-DNAs in separate Agrobacterium strains (Dutt et al., 2012). The approach of 'two T-DNAs in separate Agrobacterium strains' was adopted in this study, because the marker-free progeny has the target T-DNA sequence but does not include other redundant sequences.

Similar to the application of chemical pesticides, wide cultivation of $\mathrm{Bt}$ crops also can cause the insects to evolve resistance to $B t$ genes. The $c r y 1 A$ genes such as $c r y 1 A a$, $c r y 1 A b$, and $c r y 1 A c$ are used to control Lepidoptera pest in transgenic rice at present (Nayak et al., 1997; Cheng et al., 1998; Ye et al., 2001; Khanna and Raina, 2002). It has been reported that CrylAa, CrylAb, and CrylAc have crossresistance because of the common binding sites (Escriche et al., 1997). Thus, these proteins cannot be applied to develop $B t$ gene-stacking rice. Studies focused on transgenic insect-resistant rice with other types of $B t$ genes are rather limited so far, and there have been only a few studies about marker-free transgenic insect-resistant rice ( $\mathrm{Tu}$ et al., 2000; Kumar et al., 2010). Several previous studies have shown that the Cry2A and CrylA proteins have different binding sites in brush border membrane vesicles (BBMVs) and exhibit no cross-resistance (Lee et al., 1997; Karim and Dean, 2000; Alcantara et al., 2004; Gouffon et al., 2011). Therefore, $c r y 2 A$ gene can be applied to develop marker-free $B t$ transgenic rice. Then, the marker-free cry $2 A$ transgenic rice can be used as a resistance source for developing gene-pyramiding marker-free transgenic rice, which can delay the evolution of resistance of insects to $\mathrm{Bt}$ rice. In this study, the cry $2 A^{*}$ gene, which was synthesized by rice codon optimization with a $69.45 \%$ sequence homology with the original cry $2 \mathrm{Aa}$ gene (Chen et al., 2005), was introduced into an elite indica restorer line Minghui86
(MH86) with the purpose of developing marker-free cry2A transgenic rice.

\section{MATERIALS AND METHODS}

\section{Constructs and Genetic Transformation}

pCAMBIA1300 (provided by the Centre for the Application of Molecular Biology in International Agriculture, Australia) was digested by BstXI and XhoI to remove the CaMV35s promoter and hygromycin phosphotransferase $(h p t)$ gene, and then the cry $2 A^{*}$ gene driven by ubiquitin promoter (Christensen et al., 1992) was cloned into the multiple cloning sites to obtain the transformation vector $\mathrm{pMF}-2 \mathrm{~A}^{*}$. The T-DNA region is displayed in Supplementary Figure S1. The pMF-2A* and pCAMBIA1301 were introduced into A. tumefaciens EHA105, respectively. The two strains were used to infect an elite indica restorer line MH86 together at the ratio of 3:1. The callus culture and genetic transformation procedures were based on the method described by Lin and Zhang (Lin and Zhang, 2005).

\section{Detection of PCR and Southern Blotting}

The cry $2 A^{*}$ and $h p t$ genes were detected by PCR and Southern blotting. The primers for the amplification of $c r y 2 A^{*}$ were Cry2A-F (5'-CGTGTCAATGCTGACCTGAT-3') and Cry2A-R $\left(5^{\prime}\right.$-GATGCCGGACAGGATGTAGT-3'). The primers for the amplification of $h p t$ were hpt-F (5'-AGAATCTCGTGCTTTCA GCTTCGA-3') and hpt-R (5'-TCAAGACCAATGCGGAGC ATATAC- $3^{\prime}$ ). The PCR mixture contained $25 \mathrm{ng}$ of template DNA, $2 \mu \mathrm{l}$ of $10 \times$ buffer, $1.5 \mu \mathrm{l}$ of $2 \mathrm{mM}$ dNTP, $0.2 \mu \mathrm{l}$ of each primer $(10 \mu \mathrm{M}), 0.2 \mu \mathrm{l}$ of rtaq. The PCR reaction for the amplification of $\operatorname{cry} 2 A^{*}$ was implemented at $94^{\circ} \mathrm{C}$ for $5 \mathrm{~min} ; 32$ cycles of $94^{\circ} \mathrm{C}$ for $30 \mathrm{~s}, 57^{\circ} \mathrm{C}$ for $30 \mathrm{~s}, 72^{\circ} \mathrm{C}$ for $30 \mathrm{~s} ; 72^{\circ} \mathrm{C}$ for $7 \mathrm{~min}$. The PCR reaction to amplify $h p t$ was implemented at $94^{\circ} \mathrm{C}$ for $5 \mathrm{~min}$; $32 \mathrm{cycles}$ of $94^{\circ} \mathrm{C}$ for $30 \mathrm{~s}, 58^{\circ} \mathrm{C}$ for $30 \mathrm{~s}, 72^{\circ} \mathrm{C}$ for $30 \mathrm{~s}$; $72^{\circ} \mathrm{C}$ for $7 \mathrm{~min}$.

The total genomic DNA of the transformants was isolated by CTAB method for Southern blotting (Murray and Thompson, 1980). There are HindIII sites in the T-DNAs of pMF2A* (Supplementary Figure S1) and pCAMBIA1301, and there is no HindIII site between the probe $\left(c r y 2 A^{*}\right.$ or $\left.h p t\right)$ and LB of the T-DNA. Therefore, the DNA samples $(8 \mu \mathrm{g})$ were digested by HindIII. The plasmids pMF-2A* and pCAMBIA1301 were also digested by HindIII and $0.5 \mathrm{ng}$ of digested plasmids was loaded as positive control, respectively. The digested DNA samples were separated by $1 \%$ TAE agarose gel and transferred to nylon membrane. Each sample was hybridized by cry $2 A^{*}$ probe (a PCRamplified fragment of $c r y 2 A^{*}$ by Cry $2 \mathrm{~A}-\mathrm{F}$ and Cry $2 \mathrm{~A}-\mathrm{R}$ ) and $h p t$ probe (a PCR-amplified fragment of $h p t$ by hpt-F and hpt-R). The hybridization procedures were carried out as described by Southern (Southern, 1975).

\section{Selection of Marker-Free Homozygous Cry2A* Lines with Single Copy}

The $160 \mathrm{~T}_{1}$ generation transgenic plants derived from the $\mathrm{T}_{0}$ transgenic plant with single copy of both $c r y 2 A^{*}$ and $h p t$ were 
planted. The $\mathrm{T}_{1}$ transgenic lines containing cry $2 A^{*}$ and no $h p t$ were selected by PCR analysis, and were harvested individually. Then, the harvested seeds of these $T_{1}$ transgenic lines were sown in seedling bed and $c r y 2 A^{*}$ gene was detected in the seedlings ( $\mathrm{T}_{2}$ generation) through PCR analysis. If the $c r y 2 A^{*}$ gene did not segregate in $\mathrm{T}_{2}$ generation population derived from the same $\mathrm{T}_{1}$ plant, the $\mathrm{T}_{1}$ plant was considered as a cry $2 A^{*}$ homozygous line. Three homozygous lines were used for further assays and the presence of $c r y 2 A^{*}$ and absence of $h p t$ were confirmed by southern blotting.

\section{Measurement of Cry2A* Protein Content}

In 2016, the concentrations of Cry2A* protein in leaves (at tillering, heading and filling stage), stems (at tillering, heading and filling stage) and endosperms (at filling stage) of three transgenic homozygous lines and their hybrids were measured using the enzyme-linked immune sorbent assay (ELISA) kit AP005 from EnviroLogix Inc. (Portland, ME, USA). These hybrids were obtained by crossing the homozygous lines with II-32A, an elite indica cytoplasmic male sterility (CMS) line, respectively. Fresh leaf samples of approximately $20 \mathrm{mg}$ were collected and homogenized by grinding in $500 \mu \mathrm{l}$ of extraction buffer, and fresh stem and endosperm samples of approximately $40 \mathrm{mg}$ were collected and homogenized by grinding in $1 \mathrm{ml}$ of extraction buffer. All of the sample extracts were diluted in appropriate proportions. To quantify the Cry $2 \mathrm{~A}$ protein content, the Cry2Aa Calibrators (1, 5, and $10 \mathrm{ppb}$ ) provided by the manufacturer were used to create a standard curve. The Cry $2 \mathrm{~A}$ protein immunoassay procedures followed the protocol of the manufacturer. The optical density values were measured with a microplate reader at $450 \mathrm{~nm}$ wavelength. The Cry $2 \mathrm{~A}^{*}$ protein concentration (ppb) of each diluted sample was obtained from the standard curve. The final content of Cry $2 \mathrm{~A}^{*}$ protein was calculated according to the following equation: Cry $2 \mathrm{~A}^{*}$ protein content $(\mu \mathrm{g} / \mathrm{g})=$ [concentration value from the standard curve $(\mathrm{ppb}) \times$ dilution multiple $\times$ extraction buffer volume $(\mathrm{ml})] /$ fresh weight of each sample $(\mathrm{mg})$. To calculate the percentage of Cry $2 A^{*}$ protein, the Bradford assay (Bradford, 1976) was used to quantify the total protein concentration. One-way analysis of variance and the LSD test were used to analyze the significant difference in the mean values between different stages of transgenic lines.

\section{Insect Assay in the Laboratory}

The resistance of the transgenic lines against SSB and YSB was tested in the laboratory. The SSB were fed in our lab, and the eggs of yellow rice borers were collected in the field and hatched in laboratory. The resistance of the three transgenic homozygous lines (MH86 as the susceptible control) and their hybrids (II Youming86 produced by crossing MH86 with II$32 \mathrm{~A}$ as the susceptible control) was tested. The tested rice stems were collected from field at elongation stage and dissected into $8 \mathrm{~cm}$ in length. One glass tube $(12 \mathrm{~cm}$ in length and $2 \mathrm{~cm}$ in diameter), which contained three dissected stems, was set as a biological repeat. Fifteen first-instar larvae of SSB of YSB were placed into the tube and sealed with cotton and black gauze. Three biological repeats were performed for each tested rice line. All of the glass tubes were incubated at $28^{\circ} \mathrm{C}$ and $80 \%$ relative humidity. After 6 days the larvae mortality was investigated. One-way analysis of variance and the LSD test were used to compare the significant difference in the mean values between transgenic lines and corresponding controls.

\section{Insect Assay in the Field}

Insect resistance of the three transgenic homozygous lines in the field was evaluated at Huazhong Agricultural University experimental field in 2011, Wuhan, China. The transformation receptor MH86 was planted as susceptible control. The seeds of all tested materials were sown on rice seedling bed in June 6, 2011 and the seedlings were transplanted to paddy field in July 2. The seedlings of the four rice materials were distributed according to a randomized block design with three replications. Each replication consisted of 24 plants of each material in two rows, with a planting distance of $20 \mathrm{~cm}$ within a row and $26.7 \mathrm{~cm}$ between rows. The experimental plots were bordered by three rows of non-transgenic indica rice plants as protection. The experimental field was not sprayed with chemical pesticides during the entire growth period.

To evaluate the resistance of transgenic lines against stem borers in the field, each rice plant was infested with about 15 first-instar larvae of YSB at the booting stage. Rice dead hearts caused by stem borers was investigated after two weeks of artificial infestation. Meanwhile, leaf folds caused by natural infestation of rice leaf folder were counted. The insect resistance of transgenic hybrids and II Youming86 was evaluated in the field in 2013 using the similar method in 2011 except for that the planting distance was $17 \mathrm{~cm}$ within a row and $26.7 \mathrm{~cm}$ between rows. Because the eggs of YSB were not collected in this year, the insecticidal activity of the hybrids was evaluated under natural infestation in the experimental paddy. Non-repeated two-factor analysis of variance and LSD test were used to compare the significant difference in the mean values between transgenic lines and corresponding controls.

\section{Evaluation of Agronomic Performance in the Field}

The design of experiments for evaluating the agronomic performance of the transgenic homozygous lines and their hybrids were conducted as described above in the insect assay in the field in 2011 and 2013, respectively. Chemical insecticides were sprayed during the growth period to protect the crop. The plant height of 20 plants in the middle of each plot was measured in the field at maturity, and these plants were harvested to record the number of panicles per plant, panicle length, number of grains per panicle, 1000-grain weight, seed setting rate and yield per plant. Non-repeated two-factor analysis of variance and LSD test were also used to compare the significant difference in the mean values between transgenic lines and corresponding controls. 

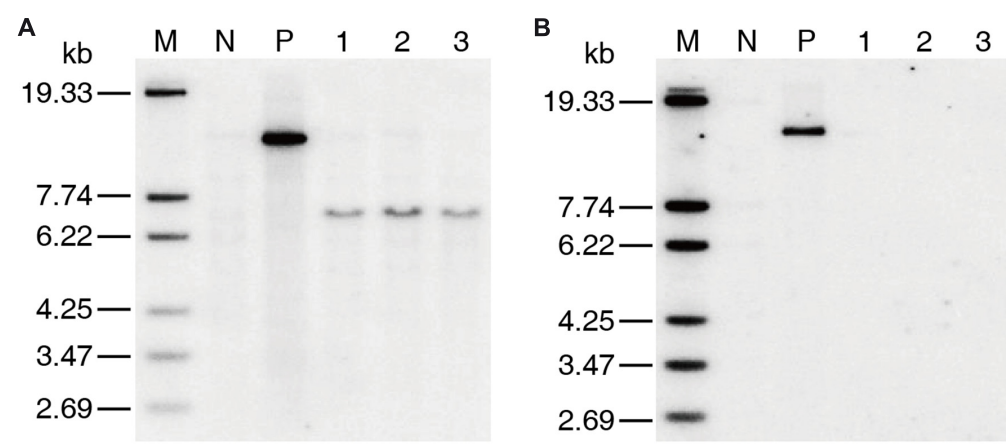

FIGURE 1 | Southern blotting of $\mathbf{T}_{\mathbf{2}}$ generation marker-free transgenic homozygous lines. (A) cry2A* probe, (B) hpt probe. M DNA Marker, N MH86 control, P positive plasmid control, 1 line 7-61, 2 line 8-30, 3 line 8-62.
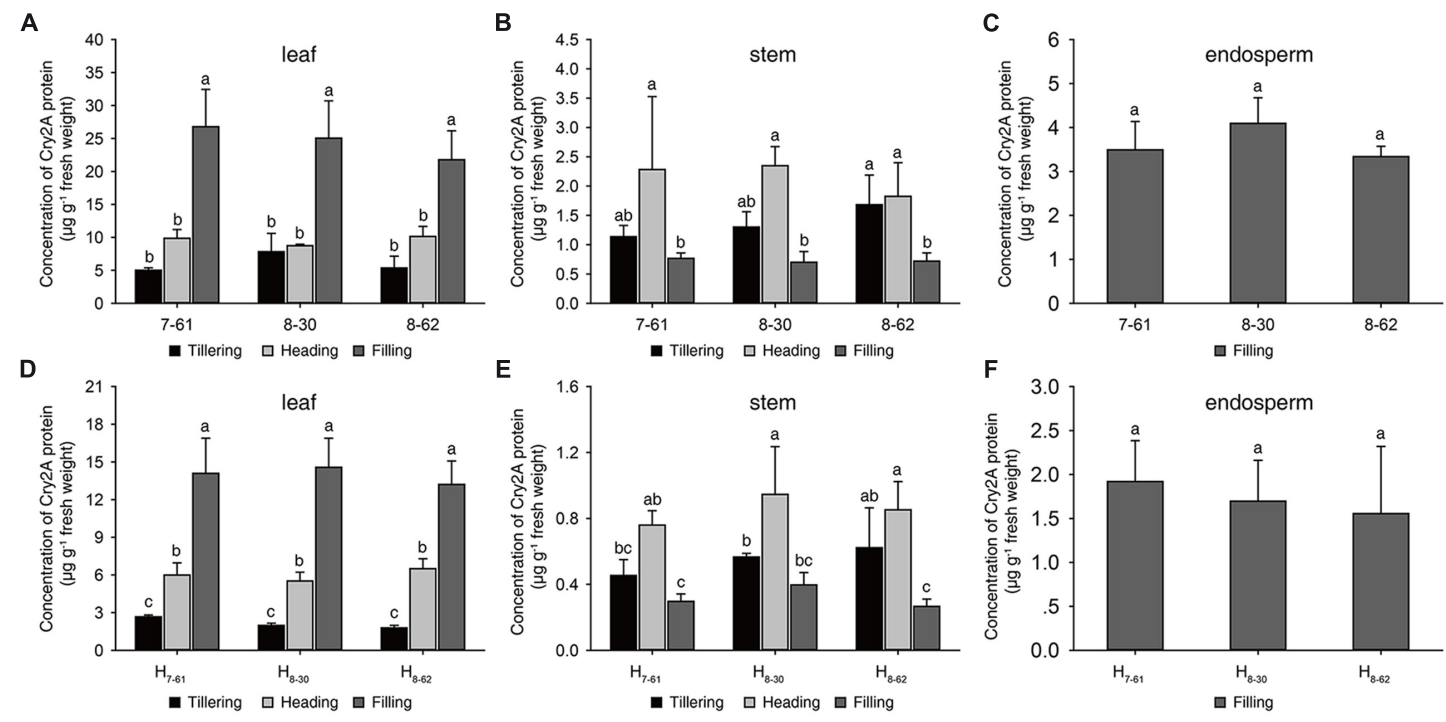

FIGURE 2 | Cry2A protein concentrations in three homozygous lines and their hybrids. (A-C) homozygous lines, (D-F) hybrids. a, b, C: significant difference at $P<0.05$. Error bars indicate SD $(n=3)$.

\section{Isolation of Flanking Sequences}

Thermal asymmetric interlaced polymerase chain reaction (TAIL PCR) was adopted for isolating the flanking sequences of the T-DNA integration site in the transgenic plant. Three nested specific primers (SP1, SP2, and SP3) near the T-DNA right border $(\mathrm{RB})$ and degenerate primer (AD8) were designed (Supplementary Table S1). The PCR mixture and reaction programs were based on the method described by Liu and Chen (2007). The tertiary amplification product was cloned to pEasy-T3 vector and sequenced. The flanking sequence of T-DNA RB flanking region was obtained by analysis of the sequencing results, and then the sequence was used for blastn in the bioinformatic website ${ }^{1}$ in order to determine the T-DNA integration site in rice genome. Meanwhile, the putative flanking

${ }^{1}$ http://rice.plantbiology.msu.edu/ sequence of T-DNA left border (LB) flanking region was obtained through querying in bioinformatic website ${ }^{2}$ according to the blastn results. The genome primer $2 \mathrm{AH} 2 \mathrm{-tF}$ based on the putative flanking sequence of LB and primer Tail-L1 in vector pMF-2A* were designed (Supplementary Table S1), and the PCR product of the two primers was sequenced to confirm the flanking sequence of LB.

\section{RESULTS}

\section{Genetic Transformation and DNA Assay}

Only two positive co-transformation plants, which were named as $2 \mathrm{AH} 1$ and $2 \mathrm{AH} 2$, respectively, were obtained in $\mathrm{T}_{0}$ generation by co-transformation of MH86 callus. The copy number of

\footnotetext{
${ }^{2}$ http://rice.plantbiology.msu.edu/cgi-bin/gbrowse/rice/\#search
} 


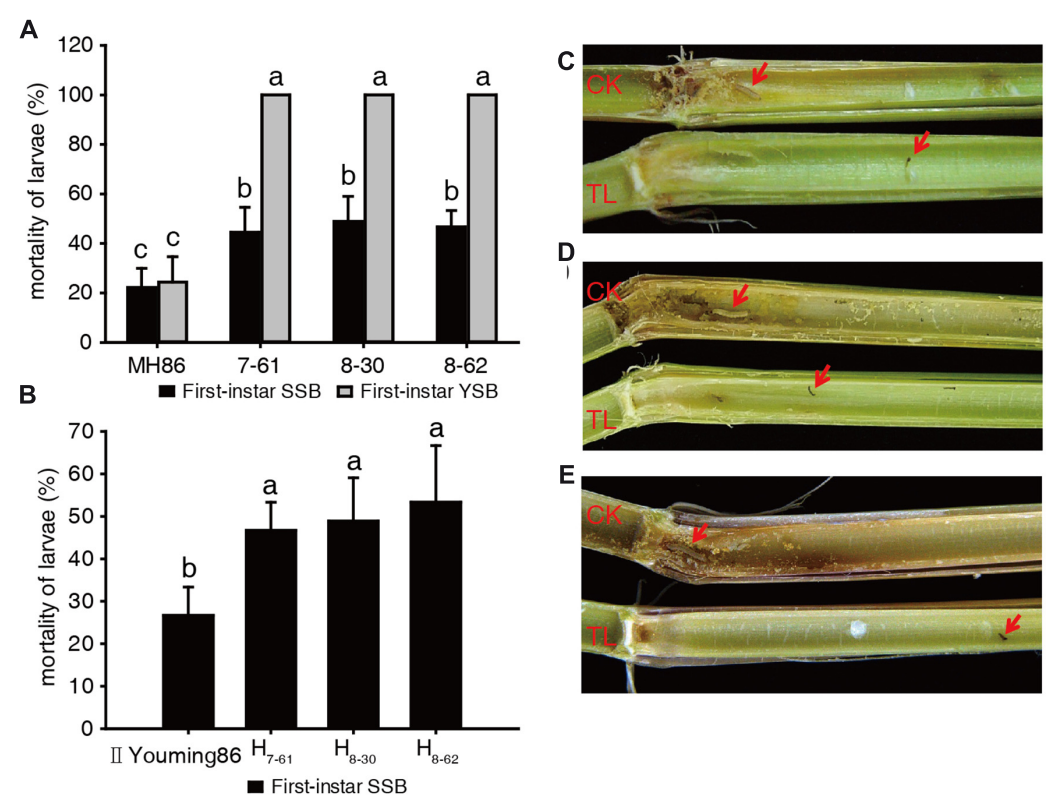

FIGURE 3 | Insect-resistance assay of transgenic materials in the laboratory. Larvae mortality of SSB and YSB fed on three transgenic homozygous lines (A); larvae mortality of SSB fed on three transgenic hybrids (B); resistance of transgenic homozygous lines against first-instar SSB (C) and YSB (D); resistance of transgenic hybrids against first-instar SSB (E). a, b, c: significant difference at $P<0.05$. Error bars indicate $\mathrm{SD}(n=3)$.

transgenic plants was confirmed by southern blotting. The results showed that both $c r y 2 A^{*}$ and $h p t$ genes were single-copy in the 2AH2 family (Supplementary Figure S2). Three marker-free homozygous lines containing $c r y 2 A^{*}$ (named as $7-61,8-30$, and 8-62) derived from $2 \mathrm{AH} 2$ were selected by PCR and southern blot analysis (Figure 1).

\section{Cry2A* Concentrations of Transgenic Homozygous Lines and Hybrids}

In 2016, the Cry2A protein contents and the percentage of Cry2A protein in soluble protein of transgenic homozygous lines were measured at tillering, heading and filling stage (Figures $2 \mathrm{~A}-\mathrm{C}$; Supplementary Table S2). In leaves, the concentrations of Cry2A protein ranged from $5.01 \mu \mathrm{g} \mathrm{g}^{-1}$ to $26.79 \mu \mathrm{g} \mathrm{g}^{-1}$ fresh weight, and the percentage of Cry2A protein ranged from 0.016 to $0.099 \%$ in soluble protein. In stems, the Cry $2 \mathrm{~A}$ protein concentrations ranged from $0.70 \mu \mathrm{g} \mathrm{g}^{-1}$ to $2.35 \mu \mathrm{g} \mathrm{g}^{-1}$ fresh weight, and the percentage of Cry $2 \mathrm{~A}$ protein ranged from 0.018 to $0.039 \%$ in soluble protein. In endosperms, the contents of Cry $2 \mathrm{~A}$ protein ranged from $3.34 \mu \mathrm{g} \mathrm{g}^{-1}$ to $4.09 \mu \mathrm{g} \mathrm{g}^{-1}$ fresh weight, and the percentage of Cry $2 \mathrm{~A}$ protein ranged from 0.026 to $0.031 \%$ in soluble protein. These results indicated that the Cry $2 \mathrm{~A}$ protein was stably expressed in the three transgenic homozygous lines at each growth stage.

To evaluate the commercial potential of the three transgenic homozygous lines, three hybrids, namely $\mathrm{H}_{7-61}, \mathrm{H}_{8-30}$, and $\mathrm{H}_{8-62}$, were produced from the crossing of II-32A with the transgenic homozygous lines, respectively. The Cry2A protein content and its proportion in soluble protein in the Bt hybrids were also measured in 2016. In the hybrids, the concentrations of Cry2A protein in leaves ranged from $1.79 \mu \mathrm{g} \mathrm{g}^{-1}$ to $14.56 \mu \mathrm{g}$ $\mathrm{g}^{-1}$ fresh weight, and the proportion of Cry $2 \mathrm{~A}$ protein ranged from 0.007 to $0.049 \%$ in soluble protein. In stems, the Cry $2 \mathrm{~A}$ protein concentrations ranged from $0.27 \mu \mathrm{g} \mathrm{g}^{-1}$ to $0.95 \mu \mathrm{g} \mathrm{g}^{-1}$ fresh weight, and the proportion of Cry $2 \mathrm{~A}$ protein ranged from 0.008 to $0.017 \%$ in soluble protein. In endosperms, the contents of Cry2A protein ranged from $1.56 \mu \mathrm{g} \mathrm{g}^{-1}$ to $1.92 \mu \mathrm{g} \mathrm{g}^{-1}$ fresh weight, and the proportion of Cry2A protein ranged from 0.012 to $0.013 \%$ in soluble protein (Figures $2 \mathrm{D}-\mathrm{F}$ and Supplementary Table S3). These results suggested that the Cry2A contents in the hybrids were lower than in the homozygous lines.

\section{Insect-Resistance of Transgenic Rice in the Laboratory}

In the laboratory assay of the insecticidal activity of the transgenic homozygous lines, the larvae mortality of SSB or YSB fed on nontransgenic control MH86 stems was approximately 22\% after

TABLE 1 | Resistance of transgenic homozygous lines against rice leaf folder and stem borers in the field under artificial infestation combined with natural infestation in 2011.

\begin{tabular}{lccc}
\hline Lines & $\begin{array}{c}\text { Number of folded } \\
\text { leaves per tiller }\end{array}$ & $\begin{array}{c}\text { Percentage of } \\
\text { tillers damaged } \\
\text { by leaffolders (\%) }\end{array}$ & $\begin{array}{c}\text { Percentage of } \\
\text { white heads (\%) }\end{array}$ \\
\hline MH86 & $2.04 \pm 0.10$ & $99.02 \pm 0.55$ & $11.84 \pm 3.34$ \\
$7-61$ & $0.11 \pm 0.02^{* *}$ & $8.23 \pm 0.65^{* *}$ & $0.00 \pm 0.00^{* *}$ \\
$8-30$ & $0.11 \pm 0.01^{* *}$ & $8.25 \pm 1.16^{* *}$ & $0.19 \pm 0.34^{* *}$ \\
$8-62$ & $0.06 \pm 0.04^{* *}$ & $4.78 \pm 2.59^{* *}$ & $0.00 \pm 0.00^{* *}$ \\
\hline
\end{tabular}

Values are the means $\pm S D(n=3)$. **Significantly different from MH86 $(P<0.01)$. 
A

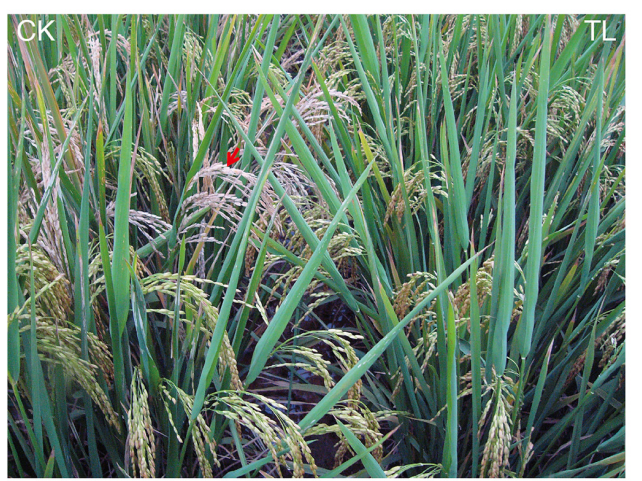

B

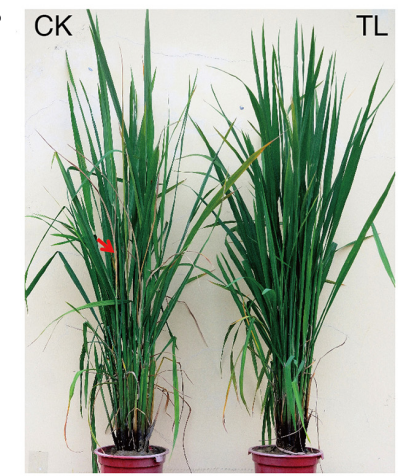

FIGURE 4 | Insect resistance performance of transgenic rice in the field. (A) Resistance of transgenic homozygous lines against rice leaf folder and rice stem borer. CK: MH86, TL: transgenic line. Red arrow indicates white head. (B) Resistance of transgenic hybrids against rice stem borer. CK: II Youming86, TL: transgenic hybrid. Red arrow indicates dead hearts.

TABLE 2 | Resistance performance of transgenic hybrids in the field after natural infestation in 2013. Values are the means \pm SD $(n=3)$.

\begin{tabular}{lcc}
\hline Lines & $\begin{array}{c}\text { Number of folded } \\
\text { leaves per tiller }\end{array}$ & $\begin{array}{c}\text { Percentage of } \\
\text { tillers damaged } \\
\text { by leaffolders (\%) }\end{array}$ \\
\hline II Youming86 & $0.18 \pm 0.06$ & $15.46 \pm 4.60$ \\
$\mathrm{H}_{7-61}$ & $0.02 \pm 0.00^{* *}$ & $1.56 \pm 0.42^{* *}$ \\
$\mathrm{H}_{8-30}$ & $0.02 \pm 0.00^{* *}$ & $1.74 \pm 0.35^{* *}$ \\
$\mathrm{H}_{8-62}$ & $0.01 \pm 0.01^{* *}$ & $1.01 \pm 0.68^{* *}$ \\
\hline
\end{tabular}

** Significantly different from II Youming86 $(P<0.01)$.

6 days, and the surviving larvae showed normal development. In addition, the MH86 stems were severely damaged and plenty of frass was observed. The larvae mortality of SSB fed on transgenic rice stems was about 50\%, and the surviving larvae showed developmental retardation: their body length was significantly shorter than that of survival from non-transgenic control MH86. Besides, there was a smaller amount of frass (Figures $3 \mathbf{A}, \mathbf{C}$ ). All YSB larvae fed on transgenic rice stem were killed after 6 days, and the stems suffered from slight damage and little frass (Figures 3A,D). These results revealed the high resistance of transgenic homozygous lines against YSB.

In the insect-resistance assay of the hybrids, the stem cuttings of II Youming86 showed similar level of damage as the stems of MH86, and the mortality of SSB larvae was about 25\%. Besides, the surviving larvae developed normally. However, the three transgenic hybrids could kill about $50 \%$ of the SSB larvae, and the development of the surviving larvae was retarded (Figures 3B,E). The results indicated that the Cry $2 \mathrm{~A}$ protein content of the transgenic hybrids was lower than that of transgenic homozygous lines, but the hybrid stems showed equivalent insecticidal activity with their parents.

\section{Insect-Resistance of Transgenic Rice in the Field}

In the insect-resistance assay of the transgenic homozygous lines in the field in 2011, the leaves of non-transgenic control MH86 showed serious folds caused by rice leaf folders. Averagely two leaves were recorded as being folded per tiller and the percentage of tillers suffering from damage per plant was up to $99 \%$. However, the percentage of tillers damaged in the three transgenic homozygous lines ranged from 4.78 to $8.25 \%$ and the leaves were only slightly damaged (0.06-0.11 leaves per tiller). Very few white heads were observed in the transgenic homozygous lines in contrast to the white heads in non-transgenic control MH86 per plant (11.84\%) (Table 1; Figure 4A).

The resistance of the transgenic hybrids against target insects in the field was evaluated under natural infestation in 2013. The damage caused by rice leaf folders was not severe in this

TABLE 3 | Agronomic performance of transgenic homozygous lines in the field.

\begin{tabular}{|c|c|c|c|c|c|c|c|}
\hline Lines & $\begin{array}{c}\text { Plant height } \\
\text { (cm) }\end{array}$ & $\begin{array}{l}\text { Panicle length } \\
\text { (cm) }\end{array}$ & $\begin{array}{l}\text { Panicles per } \\
\text { plant }\end{array}$ & $\begin{array}{l}\text { Grains per } \\
\text { panicle }\end{array}$ & $\begin{array}{l}\text { Seed setting } \\
\text { rate }(\%)\end{array}$ & $\begin{array}{l}\text { 1000-grain } \\
\text { weight }(g)\end{array}$ & $\begin{array}{l}\text { Yield per } \\
\text { plant (g) }\end{array}$ \\
\hline MH86 & $131.6 \pm 3.0$ & $28.6 \pm 0.3$ & $12.2 \pm 1.1$ & $169.7 \pm 4.8$ & $87.3 \pm 2.7$ & $29.7 \pm 0.5$ & $62.2 \pm 1.9$ \\
\hline $7-61$ & $128.2 \pm 3.4$ & $26.7 \pm 0.4^{* *}$ & $12.8 \pm 0.4$ & $179.8 \pm 2.1^{*}$ & $87.5 \pm 1.5$ & $27.1 \pm 0.5^{* *}$ & $62.1 \pm 2.1$ \\
\hline $8-30$ & $130.1 \pm 1.3$ & $27.2 \pm 0.5^{* *}$ & $13.4 \pm 0.5^{*}$ & $177.2 \pm 0.9^{*}$ & $86.7 \pm 2.3$ & $27.0 \pm 0.4^{* *}$ & $64.4 \pm 3.2$ \\
\hline $8-62$ & $125.9 \pm 1.1^{*}$ & $26.2 \pm 0.3^{* *}$ & $13.4 \pm 0.1^{*}$ & $171.2 \pm 5.6$ & $90.1 \pm 1.0$ & $25.8 \pm 0.4^{* *}$ & $58.8 \pm 2.8$ \\
\hline $\mathrm{LSD}_{0.05}$ & 3.9 & 0.8 & 1.1 & 7.0 & 4.0 & 0.9 & 4.1 \\
\hline $\mathrm{LSD}_{0.01}$ & 6.0 & 1.3 & 1.7 & 10.6 & 6.0 & 1.3 & 6.1 \\
\hline
\end{tabular}

Values are the means $\pm S D(n=3)$. *Significantly different from MH86 $(P<0.05)$; ** Significantly different from MH86 (P<0.01). 
TABLE 4 | Agronomic performance of transgenic hybrids in the field.

\begin{tabular}{|c|c|c|c|c|c|c|c|}
\hline Lines & $\begin{array}{l}\text { Plant height } \\
\text { (cm) }\end{array}$ & $\begin{array}{l}\text { Panicle length } \\
\text { (cm) }\end{array}$ & $\begin{array}{l}\text { Panicles per } \\
\text { plant }\end{array}$ & $\begin{array}{c}\text { Grains per } \\
\text { panicle }\end{array}$ & $\begin{array}{l}\text { Seed setting } \\
\text { rate }(\%)\end{array}$ & $\begin{array}{l}\text { 1000-grain } \\
\text { weight }(g)\end{array}$ & $\begin{array}{l}\text { Yield per } \\
\text { plant (g) }\end{array}$ \\
\hline |l Youming86 & $118.8 \pm 3.2$ & $28.2 \pm 0.4$ & $11.3 \pm 0.6$ & $163.8 \pm 4.2$ & $80.4 \pm 0.6$ & $26.1 \pm 0.2$ & $47.5 \pm 3.3$ \\
\hline $\mathrm{H}_{7-61}$ & $117.8 \pm 2.3$ & $26.9 \pm 0.2^{*}$ & $11.9 \pm 1.1$ & $152.8 \pm 5.4^{*}$ & $79.5 \pm 4.3$ & $25.6 \pm 0.4$ & $46.0 \pm 2.6$ \\
\hline $\mathrm{H}_{8-30}$ & $119.3 \pm 0.2$ & $27.5 \pm 1.3$ & $12.0 \pm 1.0$ & $158.0 \pm 7.4$ & $79.5 \pm 1.3$ & $25.8 \pm 0.4$ & $48.9 \pm 3.4$ \\
\hline $\mathrm{H}_{8-62}$ & $115.6 \pm 1.5^{*}$ & $27.6 \pm 1.1$ & $11.8 \pm 0.2$ & $154.6 \pm 2.2$ & $79.8 \pm 1.1$ & $25.5 \pm 0.1$ & $46.4 \pm 1.6$ \\
\hline $\mathrm{LSD}_{0.05}$ & 2.8 & 1.3 & 1.3 & 9.8 & 3.2 & 0.7 & 4.5 \\
\hline $\mathrm{LSD}_{0.01}$ & 4.0 & 1.8 & 1.8 & 13.7 & 4.4 & 1.0 & 6.3 \\
\hline
\end{tabular}

Values are the means $\pm S D(n=3)$. *Significantly different from I/ Youming $86(P<0.05)$.

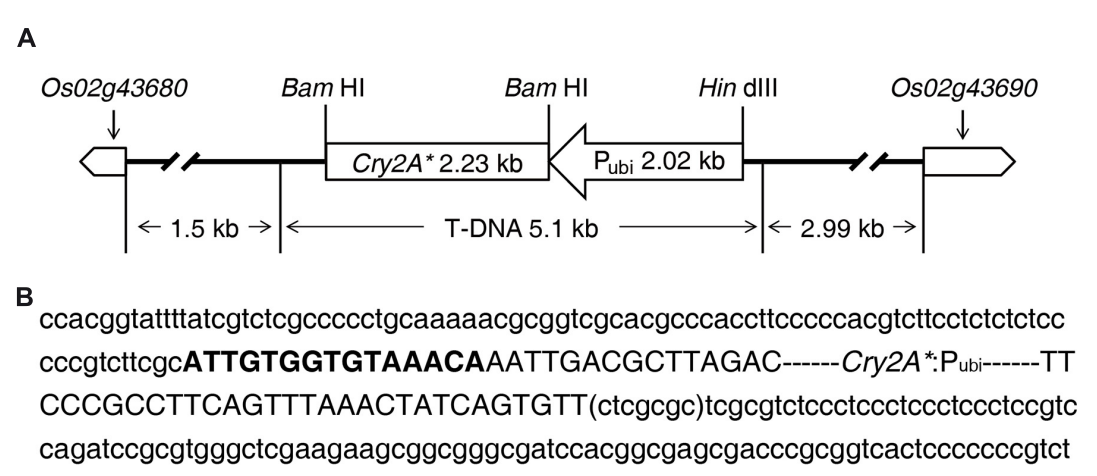

FIGURE 5 | Information of T-DNA integration site in transgenic line 8-30. (A) T-DNA inserted into rice chromosome 2 between gene Os02g43680 and gene Os02g43690. (B) Nucleotide sequences of T-DNA integration site. The two flanking sequences of T-DNA are displayed in lowercase letter. The sequence in bracket is the deletion sequence of genome. The T-DNA sequence is shown in capital letter. Bold capital letters represent the truncated T-DNA left border (LB). T-DNA right border $(\mathrm{RB})$ is missing in line $8-30$.

year. $15.46 \%$ of plant tillers suffered from damage in susceptible control II Youming86, and the transgenic hybrids showed only slight damage (Table 2). Some dead hearts caused by rice stem borers were observed in II Youming86 (Figure 4B), while almost no damage was observed in the transgenic hybrids. These results revealed that the transgenic rice was highly resistant to rice leaf folder and rice stem borer in the field.

\section{Agronomic Performance of Transgenic Rice in the Field}

Some agronomic traits of the three transgenic homozygous lines showed different degrees of variation. The panicle length and 1000-grain weight were significantly lower than those of non-transgenic control MH86 $(P<0.01)$, but the numbers of grains per panicle of line 7-61 and line 8-30 were significantly larger than that of MH86 $(P<0.05)$. All the transgenic homozygous lines showed no change in yield compared with wide-type MH86 (Table 3). The three transgenic hybrids showed little difference with non-transgenic control II Youming86 in agronomic performance, especially the hybrid of line 8-30 (Table 4).

\section{Flanking Sequences of T-DNA Integration Site in Rice Genome}

The sequence analysis results of TAIL-PCR and subsequent routine PCR revealed that one complete T-DNA copy containing cry $2 A^{*}$ gene was inserted into rice genome chromosome 2 in line $8-30$. The information of the genes nearby T-DNA integration site was obtained by querying the flanking sequence in the bioinformatics website ${ }^{3}$. The results indicated that the T-DNA LB and transcription initiation site of gene Os02g43680 had a distance of about $1.5 \mathrm{~kb}$, and the T-DNA RB was $2.99 \mathrm{~kb}$ away from the transcription initiation site of gene Os02g43690 (Figure 5A); besides, the T-DNA insertion led to a 7-bp deletion of rice genome (ctcgcgc) (Figure 5B).

\section{DISCUSSION}

In this study, a synthetic $c r y 2 A^{*}$ gene was introduced into an elite indica restorer MH86 via Agrobacterium-mediated co-transformation. Subsequently, three single-copy marker-free transgenic homozygous lines were selected by PCR analysis and Southern blotting. The three transgenic lines not only exhibited high resistance against rice leaf folder and rice stem borer (Figures 3 and 4), but also showed no significant difference in yield compared with their corresponding controls under the spraying of chemical insecticides during the entire growth period (Tables 3 and 4). In the laboratory insect assay, the larvae mortality of SSB was lower than that of YSB. This result was

\footnotetext{
${ }^{3}$ http://rice.plantbiology.msu.edu/cgi-bin/gbrowse/rice/\#search
} 
consistent with the previous study in our laboratory (Yang et al., 2011), which indicated that SSB is less susceptible to Cry2A protein than YSB. The difference in susceptibility is mainly due to the difference in Cry2A protein binding sites and binding affinities in the BBMVs of the insect midguts (Lee et al., 1997; Alcantara et al., 2004). It has been reported that the $\mathrm{LC}_{50}$ of Cry2A protein in the artificial diet for SSB was significant higher than that for YSB (Lee et al., 1997), which also suggests that Cry2A protein is more toxic to YSB than to SSB.

As we know, the presence of SMGs in transgenic plants can cause a variety of problems. Herbicide resistance genes, which can endow the transgenic plants with herbicide tolerance, are often used as selectable markers in transformation. However, the majority of SMGs are useless after the generation of transgenic plants, and their presence will increase the metabolism burden. More importantly, the presence of SMGs in transgenic plants also brings about safety concerns, particularly in rice, which is directly consumed by humans. In the past two decades, a number of marker-free plant transformation strategies have been reported and commonly used, including the Agrobacterium-mediated cotransformation and site-specific recombination. In this study, the approach 'two T-DNAs in separate Agrobacterium strains' was adopted. Two Agrobacterium strains, respectively, harboring the vector with SMG ( $h p t$ gene) and the vector with insect-resistant gene $c r y 2 A^{*}$ were used for genetic transformation, and markerfree transgenic rice was developed successfully, which might address the consumers' concerns about food safety of transgenic rice.

With the large-scale cultivation of Bt transgenic crops, the insect populations that evolve resistance to $\mathrm{Bt}$ proteins have been found in the field. The evolution of insect resistance is mainly due to the mutation of cadherin, which binds with Bt protein in the midgut of insect. Gene pyramiding is an effective strategy to deal with insect resistance. The cry $1 A$ genes, including $c r y 1 A b, c r y 1 A c$, and the fusion gene cry $1 A b / A c$, are most commonly used in transgenic rice so far, especially in marker-free transgenic rice. The proteins encoded by cry $1 A$ genes have common binding sites in the BBMVs of insect midgut, and they have cross-resistance between each other. Therefore, other types of $B t$ genes should be combined with $\operatorname{cry} 1 \mathrm{~A}$ genes to develop gene-stacking $\mathrm{Bt}$ transgenic rice. In this study, the marker-free transgenic rice expressing Cry2A protein, which showed different binding sites with CrylA protein in the midgut of SSB or YSB, can be used to cross with marker-free CrylA transgenic rice for developing marker-free transgenic rice with double $B t$ genes to delay the evolution of insect resistance. The marker-free

\section{REFERENCES}

Alcantara, E. P., Aguda, R. M., Curtiss, A., Dean, D. H., and Cohen, M. B. (2004). Bacillus thuringiensis $\delta$-endotoxin binding to brush border membrane vesicles of rice stem borers. Arch. Insect Biochem. Physiol. 55, 169-177. doi: 10.1002/arch.10128

Bradford, M. M. (1976). A rapid and sensitive method for the quantitation of microgram quantities of protein utilizing the principle of protein-dye binding. Anal. Biochem. 72, 248-254. doi: 10.1016/0003-2697(76)90527-3 cry $1 A b / A c$ transgenic indica rice TT51 developed previously by our laboratory has been issued with security certificate again by Chinese government in 2014, indicating the great commercialization potential of marker-free $\mathrm{Bt}$ transgenic rice. Thus, it can be speculated that the marker-free $c r y 2 A^{*}$ transgenic rice developed in this study has the similar potential for commercialization.

The results of flanking sequence isolation revealed that T-DNA containing $c r y 2 A^{*}$ was integrated into the intergenic region of chromosome 2 (Figure 5). Although the transgenic homozygous lines were significantly different from nontransgenic wide-type MH86 in several agronomic traits (Table 3), the transgenic hybrids showed little difference from the nontransgenic control II Youming86 in agronomic performance (Table 4). These results suggest that the variations of agronomic traits in transgenic homozygous lines might be caused by the somatic mutation in the tissue culture. However, most of these variations were recovered in the hybrids. Yang et al. (2011) reported the similar results when they recorded the agronomic traits of the hybrids derived from four single $B t$-gene transgenic rice lines and 10 two $B t$-gene transgenic rice lines crossing with an indica CMS Zhenshan97A, respectively. These results suggest that the consecutive backcross of the transgenic homozygous line 8-30 with the wide-type MH86 can eliminate the somatic variations (Bregitzer et al., 2008; Yang et al., 2012).

\section{AUTHOR CONTRIBUTIONS}

FL, FZ, HC, and YL designed the experiments. FL performed the experiments, collected, and analyzed the data. FL and YL wrote the manuscript.

\section{ACKNOWLEDGMENTS}

This research was funded by the National Program of Transgenic Variety Development of China (2016ZX08001-001) and the National High Technology Research and Development Program of China (863 Program). And we thank Prof. Zuoxiong Liu (Huazhong Agricultural University) for language improvement.

\section{SUPPLEMENTARY MATERIAL}

The Supplementary Material for this article can be found online at: http://journal.frontiersin.org/article/10.3389/fpls.2016.01608/ full\#supplementary-material

Bregitzer, P., Dahleen, L. S., Neate, S., Schwarz, P., and Manoharan, M. (2008). A single backcross effectively eliminates agronomic and quality alterations caused by somaclonal variation in transgenic barley. Crop Sci. 48, 471-479. doi: 10.2135/cropsci2007.06.0370

Breitler, J. C., Meynard, D., Van Boxtel, J., Royer, M., Bonnot, F., Cambillau, L., et al. (2004). A novel two T-DNA binary vector allows efficient generation of marker-free transgenic plants in three elite cultivars of rice (Oryza sativa L.). Transgenic Res. 13, 271-287. doi: 10.1023/B:TRAG.0000034626. 22918.0a 
Chen, H., Lin, Y., and Zhang, Q. (2009). Review and prospect of transgenic rice research. Chin. Sci. Bull. 54, 4049-4068. doi: 10.1007/s11434-0090645-x

Chen, H., Tang, W., Xu, C., Li, X., Lin, Y., and Zhang, Q. (2005). Transgenic indica rice plants harboring a synthetic cry $2 \mathrm{~A}^{*}$ gene of Bacillus thuringiensis exhibit enhanced resistance against lepidopteran rice pests. Theor. Appl. Genet. 111, 1330-1337. doi: 10.1007/s00122-005-0062-8

Cheng, X., Sardana, R., Kaplan, H., and Altosaar, I. (1998). Agrobacteriumtransformed rice plants expressing synthetic cryIA (b) and cryIA (c) genes are highly toxic to striped stem borer and yellow stem borer. Proc. Natl. Acad. Sci. U.S.A. 95, 2767-2772. doi: 10.1073/pnas.95.6. 2767

Christensen, A. H., Sharrock, R. A., and Quail, P. H. (1992). Maize polyubiquitin genes: structure, thermal perturbation of expression and transcript splicing, and promoter activity following transfer to protoplasts by electroporation. Plant Mol. Biol. 18, 675-689. doi: 10.1007/BF00020010

Clive, J. (2012). Global Status of Commercialized Biotech/GM Crops: 2012. Ithaca, NY: ISAAA.

de Vetten, N., Wolters, A. M., Raemakers, K., Van Der Meer, I., Ter Stege, R., Heeres, E., et al. (2003). A transformation method for obtaining marker-free plants of a cross-pollinating and vegetatively propagated crop. Nat. Biotechnol. 21, 439-442. doi: 10.1038/nbt801

Dutt, M., Li, Z. T., Dhekney, S. A., and Gray, D. J. (2012). Co-transformation of grapevine somatic embryos to produce transgenic plants free of marker genes. Methods Mol. Biol. 847, 201-213. doi: 10.1007/978-1-61779558-9_17

Endo, S., Sugita, K., Sakai, M., Tanaka, H., and Ebinuma, H. (2002). Singlestep transformation for generating marker-free transgenic rice using the ipt-type MAT vector system. Plant J. 30, 115-122. doi: 10.1046/j.1365313X.2002.01272.x

Escriche, B., Ferré, J., and Silva, F. J. (1997). Occurrence of a common binding site in Mamestra brassicae, Phthorimaea operculella, and Spodoptera exigua for the insecticidal crystal proteins CryIA from Bacillus thuringiensis. Insect Biochem. Mol. Biol. 27, 651-656.

Gao, X., Zhou, J., Li, J., Zou, X., Zhao, J., Li, Q., et al. (2015). Efficient generation of marker-free transgenic rice plants using an improved transposonmediated transgene reintegration strategy. Plant Physiol. 167, 11-24. doi: 10.1104/pp.114.246173

Gouffon, C., Van Vliet, A., Van Rie, J., Jansens, S., and Jurat-Fuentes, J. (2011). Binding sites for Bacillus thuringiensis Cry2Ae toxin on heliothine brush border membrane vesicles are not shared with CrylA, CrylF, or Vip3A toxin. Appl. Environ. Microbiol. 77, 3182-3188. doi: 10.1128/AEM. 02791-10

Karim, S., and Dean, D. (2000). Toxicity and receptor binding properties of Bacillus thuringiensis $\delta$-endotoxins to the midgut brush border membrane vesicles of the rice leaf folders, Cnaphalocrocis medinalis and Marasmia patnalis. Curr. Microbiol. 41, 276-283. doi: 10.1007/s0028400 10134

Khan, R. S., Chin, D. P., Nakamura, I., and Mii, M. (2006). Production of markerfree transgenic Nierembergia caerulea using MAT vector system. Plant Cell Rep. 25, 914-919. doi: 10.1007/s00299-006-0125-6

Khanna, H. K., and Raina, S. K. (2002). Elite Indica transgenic rice plants expressing modified Cry1 Ac endotoxin of Bacillus thuringiensis show enhanced resistance to yellow stem borer (Scirpophaga incertulas). Transgenic Res. 11, 411-423. doi: 10.1023/A:1016378606189

Kumar, S., Arul, L., and Talwar, D. (2010). Generation of marker-free Bt transgenic indica rice and evaluation of its yellow stem borer resistance. J. Appl. Genet. 51, 243-257. doi: 10.1007/BF03208854

Lee, M. K., Aguda, R., Cohen, M., Gould, F., and Dean, D. (1997). Determination of binding of Bacillus thuringiensis (delta)-endotoxin receptors to rice stem borer midguts. Appl. Environ. Microbiol. 63, 1453-1459.

Li, Z., Xing, A., Moon, B. P., Burgoyne, S. A., Guida, A. D., Liang, H., et al. (2007). A Cre/loxP-mediated self-activating gene excision system to produce marker gene free transgenic soybean plants. Plant Mol. Biol. 65, 329-341. doi: 10.1007/s11103-007-9223-2

Lin, Y. J., and Zhang, Q. (2005). Optimising the tissue culture conditions for high efficiency transformation of indica rice. Plant Cell Rep. 23, 540-547. doi: 10.1007/s00299-004-0843-6
Liu, Y.-G., and Chen, Y. (2007). High-efficiency thermal asymmetric interlaced PCR for amplification of unknown flanking sequences. BioTechniques 43, 649-656. doi: 10.2144/000112601

Matheka, J. M., Anami, S., Gethi, J., Omer, R. A., Alakonya, A., Machuka, J., et al. (2013). A new double right border binary vector for producing marker-free transgenic plants. BMC Res. Notes 6:448. doi: 10.1186/1756-05006-448

Murray, M. G., and Thompson, W. F. (1980). Rapid isolation of high molecular weight plant DNA. Nucleic Acids Res. 8, 4321-4325. doi: 10.1093/nar/8.19. 4321

Nayak, P., Basu, D., Das, S., Basu, A., Ghosh, D., Ramakrishnan, N. A., et al. (1997). Transgenic elite indica rice plants expressing CryIAc $\partial$-endotoxin of Bacillus thuringiensis are resistant against yellow stem borer (Scirpophaga incertulas). Proc. Natl. Acad. Sci. U.S.A. 94, 2111-2116. doi: 10.1073/pnas.94. 6.2111

Parkhi, V., Rai, M., Tan, J., Oliva, N., Rehana, S., Bandyopadhyay, A., et al. (2005). Molecular characterization of marker-free transgenic lines of indica rice that accumulate carotenoids in seed endosperm. Mol. Genet. Genomics 274, 325-336. doi: 10.1007/s00438-005-0030-7

Qiu, C., Sangha, J. S., Song, F., Zhou, Z., Yin, A., Gu, K., et al. (2010). Production of marker-free transgenic rice expressing tissue-specific Bt gene. Plant Cell Rep. 29, 1097-1107. doi: 10.1007/s00299-010-0893-x

Scaramelli, L., Balestrazzi, A., Bonadei, M., Piano, E., Carbonera, D., and Confalonieri, M. (2009). Production of transgenic barrel medic (Medicago truncatula Gaernt.) using the ipt-type MAT vector system and impairment of Recombinase-mediated excision events. Plant Cell Rep. 28, 197-211. doi: 10.1007/s00299-008-0634-6

Sengupta, S., Chakraborti, D., Mondal, H. A., and Das, S. (2010). Selectable antibiotic resistance marker gene-free transgenic rice harbouring the garlic leaf lectin gene exhibits resistance to sap-sucking planthoppers. Plant Cell Rep. 29, 261-271. doi: 10.1007/s00299-010-0819-7

Shiva Prakash, N., Bhojaraja, R., Shivbachan, S. K., Hari Priya, G. G., Nagraj, T. K., Prasad, V., et al. (2009). Marker-free transgenic corn plant production through co-bombardment. Plant Cell Rep. 28, 1655-1668. doi: 10.1007/s00299009-0765-4

Southern, E. M. (1975). Detection of specific sequences among DNA fragments separated by gel electrophoresis. J. Mol. Biol. 98, 503-517. doi: 10.1016/S00222836(75) 80083-0

Sripriya, R., Raghupathy, V., and Veluthambi, K. (2008). Generation of selectable marker-free sheath blight resistant transgenic rice plants by efficient cotransformation of a cointegrate vector T-DNA and a binary vector T-DNA in one Agrobacterium tumefaciens strain. Plant Cell Rep. 27, 1635-1644. doi: 10.1007/s00299-008-0586-x

Tu, J., Zhang, G., Datta, K., Xu, C., He, Y., Zhang, Q., et al. (2000). Field performance of transgenic elite commercial hybrid rice expressing Bacillus thuringiensis $\delta$-endotoxin. Nat. Biotechnol. 18, 1101-1104. doi: 10.1038/80310

Woo, H.-J., Lee, S. B., Qin, Y., Lim, M.-H., Lee, J.-H., Shin, K.-S., et al. (2015a). Generation and molecular characterization of marker-free Bt transgenic rice plants by selectable marker-less transformation. Plant Biotechnol. Rep. 9, 351360. doi: 10.1007/s11816-015-0371-6

Woo, H. J., Qin, Y., Park, S. Y., Park, S. K., Cho, Y. G., Shin, K. S., et al. (2015b). Development of selectable marker-free transgenic rice plants with enhanced seed tocopherol content through FLP/FRT-mediated spontaneous auto-excision. PLoS ONE 10:e0132667. doi: 10.1371/journal.pone.0132667

Yang, Z., Chen, H., Tang, W., Hua, H., and Lin, Y. (2011). Development and characterisation of transgenic rice expressing two Bacillus thuringiensis genes. Pest Manag. Sci. 67, 414-422. doi: 10.1002/ps.2079

Yang, Z., Chen, H., Tang, W., and Lin, Y.-J. (2012). Effect of successive backcrossing on eliminating somaclonal variation caused by Agrobacteriummediated transformation in rice. Acta Agron. Sin. 38, 814-819. doi: 10.3724/SP.J.1006.2012.00814

Ye, G. Y., Shu, Q. Y., Yao, H. W., Cui, H. R., Cheng, X. Y., Hu, C., et al. (2001). Field evaluation of resistance of transgenic rice containing a synthetic cryl $\mathrm{Ab}$ gene from Bacillus thuringiensis Berliner to two stem borers. J. Econ. Entomol. 94, 271-276. doi: 10.1603/0022-0493-94.1.271

Yu, Y., Wang, Y., Tong, Q., Liu, X., Su, F., Quan, F., et al. (2013). A sitespecific recombinase-based method to produce antibiotic selectable marker free transgenic cattle. PLoS ONE 8:e62457. doi: 10.1371/journal.pone.0062457 
Zubko, E., Scutt, C., and Meyer, P. (2000). Intrachromosomal recombination between attP regions as a tool to remove selectable marker genes from tobacco transgenes. Nat. Biotechnol. 18, 442-445. doi: 10.1038/74515

Conflict of Interest Statement: The authors declare that the research was conducted in the absence of any commercial or financial relationships that could be construed as a potential conflict of interest.
Copyright (๑) 2016 Ling, Zhou, Chen and Lin. This is an open-access article distributed under the terms of the Creative Commons Attribution License (CC BY). The use, distribution or reproduction in other forums is permitted, provided the original author(s) or licensor are credited and that the original publication in this journal is cited, in accordance with accepted academic practice. No use, distribution or reproduction is permitted which does not comply with these terms. 